\title{
First Record of Aspergillus flavus as a Fungal Pathogen of the Predator Rhynocoris marginatus (Hemiptera: Reduviidae)
}

\author{
Kitherian Sahayaraj ${ }^{\bowtie}$, Jesu Alexander Francis Borgio², Subramanian Muthu Kumar3
}

1. Crop Protection Research Centre, St. Xavier’s College, e-mail: ksraj42@gmail.com (Corresponding Author ${ }^{\bowtie}$ ). 2. Prince Mohammed Centre for Research \& Consultation, University Of Dammam, e-mail: fbalexander@ud.edu.sa. 3. St. Hindu College, Nagercoil, Tamil nadu, India, e-mail: smkkurichi@gmail.com

EntomoBrasilis 5 (1): 8o-81 (2012)

Abstract. An entomopathogenic fungus, Aspergillus flavus Raper and Fennell is recorded for the first time as a pathogen of the predator Rhynocoris marginatus (Fab.) (Hemiptera: Reduviidae) in natural agro-ecosystems of Tirunelveli District, Tamil Nadu, India.

Keywords: Natural enemy; Microbe, Pathogen; Reduviid predator.

\section{Primeiro Registro de Aspergillus flavus como Patógeno do Predador Rhynocoris marginatus (Hemiptera: Reduviidae)}

Resumo. O fungo entomopatogênico Aspergillus flavus Raper and Fennell é registrado pela primeira vez como um patógeno do predador Rhynocoris marginatus (Fab.) (Hemiptera: Reduviidae) em agroecossistema natural no distrito de Tirunelveli, Tamil Nadu, Índia.

Palavras-chaves: Inimigo Natural; Micro-organismo; Predador; Reduviídeo predador.

$\mathbf{T}$ The reduviid predator, Rhynocoris marginatus (Fab.) is an entomophagous insect distributed in many agroecosystems and feeding on more than twenty economically important insect pests in India (SAHAYARAJ 2007) (Figure 1). The potential of $R$. marginatus as a biocontrol agent under laboratory (SAHAYARAJ 2000; SAHAYARAJ \& BALASUBRAMANiAn 2009) and field conditions (SAHAYARAJ \& MARTIN 2003; SAHAYARAJ \& RAVI 2007) has been reported earlier. SAHAYARAJ (2007) reported that the egg cluster of this bug was parasitized by a hymenopteran parasitoid, Trissolcus sp. So far no information is available about the microbial pathogen of this biological control agent. Here, we recorded a fungal pathogen which infects the life stages of $R$. marginatus both in laboratory and field condition for the first time.

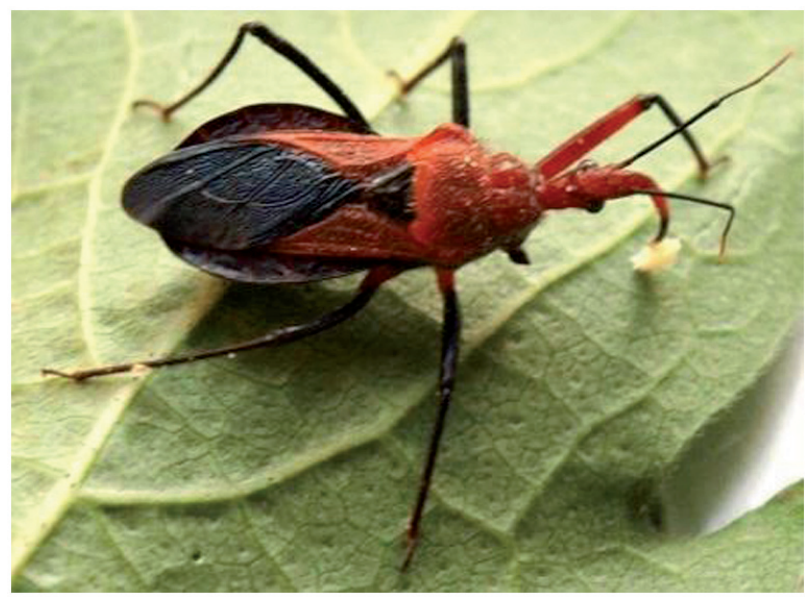

Figure 1. Rhynocoris marginatus female feeding on Phenacoccus solenopsis Tinsley (Hemiptera: Pseudococcidae).
Six males and four females of $R$. marginatus was collected from agro-ecosystems and maintained under laboratory conditions at $30 \pm 1{ }^{\circ} \mathrm{C}, 70-80 \% \mathrm{RH}$ and with a photoperiod of 11: $13 \mathrm{~h} \mathrm{D}: \mathrm{L}$ for one week. Mycelial scarbed out from the dead predator was cultured in $15 \mathrm{~mL}$ Sabouraud dextrose agar medium at $30^{\circ} \mathrm{C}$ for $12 \mathrm{~h}$. Microscopic examination of fungal mass revealed large number of spores born on conidiospores. On the basis of colonial morphology and microscopic characteristics (ABUBACKER \& RAMANATHAN 2003 and CAPPUCCINO \& SHERMAN 2004) the isolated fungus was identified as Aspergillus flavus Raper and Fennell. The fungus isolated from such infected predator has satisfied the Koch's postulates. In another study, $10^{6}$ conidia/mL suspensions was prepared from the 5-day old PDA slant culture, sprayed over the body of the healthy adult predators and recorded the mortality if any for a period of seven days. Thirty individuals (15 each of male and female) were maintained for this study.

During our field visit in Sivanthipatti ( $77^{\circ} 47^{\prime} \mathrm{E}$ and $\left.8^{\circ} 30^{\prime} \mathrm{N}\right)$, Tirunelveli District, Tamil Nadu, India on fourth April 2005, live adult $R$. marginatus (six males and four females) were collected and brought to the laboratory. Next day we observed that 20 per cent of the collected predators were dead, and after five day of infection predators were mummified. Initially white mycelial growth was observed in the infected predators. Pale yellow mycelial growth appeared after 48 hours. After four days, the mycelial color turned to yellowish-green as originally in infected predator. Conidia of $A$. flavus were not virulent when applied to the surface of healthy Galleria mellonella (Linn.) caterpillars (RAYMond et al. 2000). However, these fungi could, colonize, killed insects and produced spores on reduviid cadavers within 4 days of infection.

Thepathogenicitytest showed that an average of $96.6 \%$ of mortality was recorded within 4 days in the treated adult predators under 
laboratory conditions. The mycelial growth appeared fourth day after inoculation. From the dead adult, the fungus was re-isolated and checked with healthy predators. Similar pathogenicty was recorded again. Numbers of previous reports are available on the presence of aflotoxins, secondary metabolites from fungus, $A$. flavus in foods and feeds, cause serious economic loss, apart from their carcinogenic potentials and insecticidal ability (Doyle et al. 1982; Hagler et al. 1983; Mislivec et al. 1988; Kumar \& Prasad 1992 and Abubacker \& Ramanathan 2003). Selvaraj et al. (2002) reported that $A$. flavus infect various life stages of red cotton bug, Dysdercus cingulatus (Fab.) during laboratory rearing. But there are no records available about the infection of $A$. flavus on reduviid predators.

\section{ACKNOWLEDGEMENT}

K. Sahayaraj is thankful to Council of Scientific and Industrial Research, Govt. of India for the financial assistance (ref. No. 37/1350/o8/EMRII). The authors are highly thankful to the authorities of St. Xavier's College (Autonomous), Palayamkottai for providing necessary laboratory facilities and the encouragements.

\section{REFERENCES}

Abubacker, M.N. \& R. Ramanathan, 2003. Efficacy of Euphoria splendens and Leonotis nepetaefolia on aflatoxin producing fungi Aspergillus flavus and Aspergillus parasiticus. Indian Journal of Experimental Biology, 41: 1473-1475.

Cappuccino, G.J. \& N. Sherman, 2004. Microbiology - A lab manual. Addion-Wesley Longman, Inc. Mexicocity.

Doyle, M.P., R.S. Applebaum, R.E, Brackeet \& E. H. Marth, 1982. Physical, chemical and biological degradation of mycotoxins in foods and agricultural comodites. Journal of Food Protection, 45: 964-966.

Hagler, W. M. Jr., J.E. Hutchin \& P.B. Hamilton, 1983. Destruction of aflotoxin B1 with sodium bisulfite- isolation of major product aflotoxin B1 S. Journal of Food Protection, 46: 295-298.
Kumar, S. \& G. Prasad, 1992. Efficacy of medicinal plant (Andrographis peniculata) extracts on aflotoxins production and growth of aflatoxin Aspergillus flavus. Letter of Applied Microbiology, 15: 131-135.

Leger, R.J. St., S.E. Screen, \& B. Shams-Pirzadeh, 2000. Lack of host specialization in Aspergillus flavus Applied Environmental Microbiology, 66: 320-324.

Mislivec, P. B., M. E. Trucksess, \& L. Stoloff, 1988. Effect of other toxigenic mold species on aflatoxins production by Aspergillus flavus in sterile broth shake culture. Journal of Food Protection, 51: 449-451.

Sahayaraj, K., 2000. Evaluation of Biological control potential of Rhynocoris marginatus (Fab.) on four groundnut pests under laboratory conditions. International Arachis Newsletter, 20: 72-74.

Sahayaraj, K., 2004. Indian insect predators in biological control. Daya Publication House, Delhi. 326 p.

Sahayaraj, K., 2007. Pest Control Mechanism of Rediviids, Oxford Book Company, Narayan Niwas, Jaipur, India, 204 p.

Sahayaraj, K. \& P. Martin, 2003. Assessment of Rhynocoris marginatus (Fab.) (Hemiptera: Reduviidae) as augmented control in groundnut pests. Journal of Central European Agriculture, 4:103-110.

Sahayaraj, K. \& R. Balasubramanian, 2009. Biological control potential of artificial diet and insect hosts reared Rhynocoris marginatus (Fab.) on three pests. Archives of Phytopathology and Plant Protection, 42: 238-247.

Sahayaraj, K. \& C. Ravi, 2007. Evaluation of reduviid predators and plant products against chosen groundnut pests. Archives of Phytopathology and Plant Protection, 40 (4): 281-290.

Selvaraj, S., S. Janarthanan, \& P. Suresh, 2002 Aspergillus flavus an insect pathogen on red cotton bug, Dysdercus cingulatus (Fab.) (Heteroptera: Pyrrhocoridae). Insect Environment, 8: 125-126.

\section{Recebido em: 23/o7/2011}

Aceito em: 28/10/2011

\section{Como citar este artigo:}

Sahayaraj, K, J.A.F. Borgio \& S.M. Kumar, 2012. First Record of Aspergillus flavus as a Fungal Pathogen of the Predator Rhynocoris marginatus (Hemiptera: Reduviidae). EntomoBrasilis, 5(1): 8o-81.

Acessível em: http://www.periodico.ebras.bio.br/ojs/index.php/ebras/article/view/175
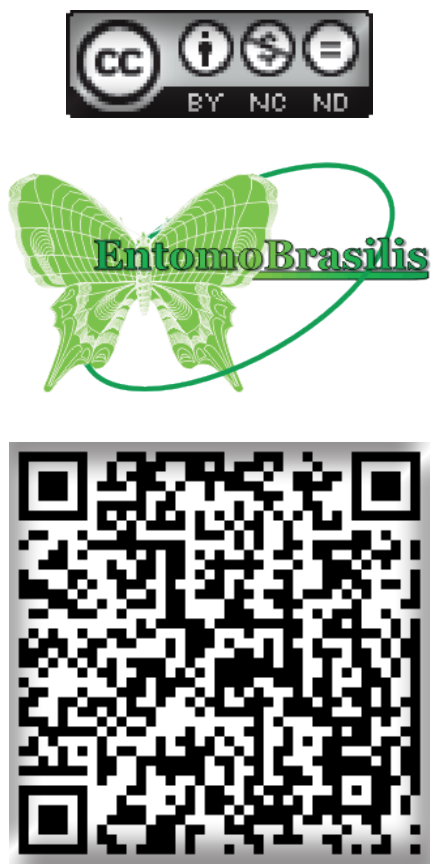